\title{
EfFects of Principals' Provision of Teaching AND LEARNING MATERIALS ON STUDENTS' PERFOMANCE IN MATHEMATICS IN KENYA CERTIFICATE OF SECONDARY EDUCATION IN MERU COUNTY
}

\author{
Honjen Kirikua Thiharu Maingi, Paul Maithya, and Alexander Ronoh \\ Maasai Mara University, Kenya
}

\begin{abstract}
In the past few years, Mathematics performance among secondary school learners in Meru County has been decreasing. The current study aims to evaluate various administrative strategies used by principals and their effects on learners' grade attainment in Kenya Certificate of Secondary Educationin Meru County. The study examines ways through which principals support mathematics teachers through trainings, seminars, workshops and how the support is translated into students' performance. The study adopted ex post facto design to collect data and analyze the information for conclusion. The researcher analyzed KCSE data over the previous 5 years in Meru County, interviewed the principals, and designed questionnaire for Mathematics teachers. A total of 836 Mathematics teachers and 299 principals across the county were targeted.Using stratified and random sampling, only 251 Mathematics teachers and 92 principals were engaged, which accounts for only $30 \%$ of the target. The researcher used split half technique to test reliability and instrument piloting to ensure validity of the data. The study concluded that principals provided little support to Mathematics teachers to attend seminars and workshops. However, principals defended this by citing low resource budget allocations and inadequate resources to support teachers' seminars and workshops. The findings of the current study can be used by education ministry, school administrator, teachers, and other stakeholders during the decision-making.
\end{abstract}

\section{KEYWORDS}

Mathematics; KCSE; performance; principals; administrative strategies;

\section{INTRODUCTION}

Up to the secondary level of education in Kenya, Mathematics is a core subject which means all the students have to take it up as one of their study subjects. This is because Mathematics forms the basis of other career fields including engineering, commerce, agriculture, medicine, architecture among others.

Despite the government of Kenya providing free secondary funds and prioritizing Mathematics. Mathematics performance at the secondary school level has continued to decline for the last five years in Meru County, from 2012 to 2016. Mathematics scores have been below average (2.8), which is averaged from the mean obtained between 2012 and 2016, an indication of grade D plain on average. However, in neighboring counties of Tharaka-Nithi and Embu had a mean of 4.5 within the same period, which are grade $\mathrm{D}+$ and 4.91 which is grade $\mathrm{C}$ - respectively. 
Although several studies have been conducted on the contribution of administrative role of school principals on student performance, there is limited information on evaluation of principals' administrative strategies on student performance in Mathematics and especially in Meru County.

The purpose of the study was an evaluation of effects of principals' administrative strategies on students' performance in Mathematics in Kenya certificate of secondary education in Meru County, Kenya

\section{Methodology}

This study used ex-post facto design. Data collection was conducted from 299 principals and 836 Mathematics teachers of secondary schools in Meru County, Kenya.For selecting schools in the different categories, stratified random sampling with proportional allocation was employed. The method will ensure that the characteristics of the three sub-groups are represented. In each category, the researcher employed simple random sampling to determine the specific school that was visited. The same procedure applied to identification of respondents. The research instruments that aided in conducting this study were:Mathematics Teachers' questionnaire andPrincipal's Interview guide. All the instruments were developed by the researcher.To ascertain the validity and reliability of the data collection questionnaires, pilot survey was conducted.To ensure the validity of the research instrument the researcher ensured that each specific objective, questions of study and objectives were addressed by items in the questionnaire.Reliability refers to the consistency of results on replication of the same study using the same instrument (Bryman, 2012). It is generally understood to be the extent to which a measure is stable or consistent and produces similar result when administered repeatedly (Sushil \& Verma, 2010). This study used split-half technique.Chi-square was used to test the Hypotheses to evaluate the relationship between independent and dependent variables. The confidence level of hypotheses testing was 0.05. Once the data was collected, it was post-coded and analyzed using the Statistical Package for Social Sciences (SPSS) with help of computer software. Quantitative data gathered from closed ended questions was summarized and organized into similar themes as per the research questions. It was analyzed using frequency distribution table's percentages. Quantitative data presentation was through tables, percentages and normal distribution tables.

\section{FINDINGS}

The study found out that provision of learning and teaching materials affected students' performance in Mathematics in K.C.S.E in Meru County. The researcher asked the teachers to indicate whether or not in their schools they were provided with learning and teaching resources by the principals, and their responses were as documented in the Figure 1 


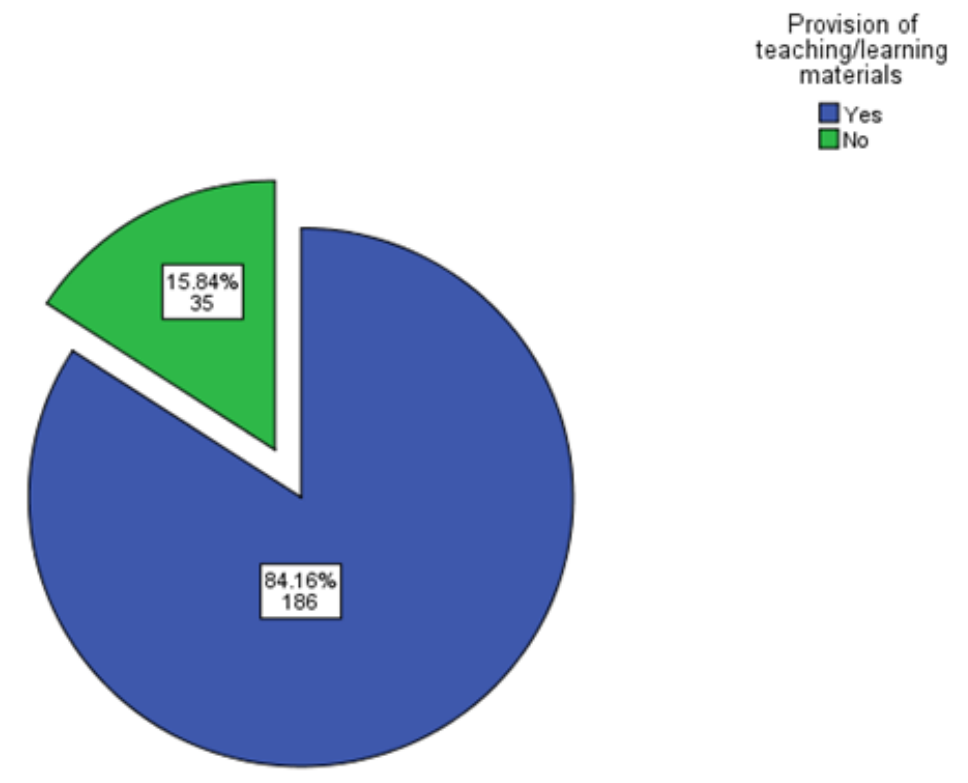

Figure 1: Provision of teaching and learning materials

The Figure 1 shows that the majority of Mathematics teachers $186(8.4 .16 \%)$ concurred that their principals provided teaching and learning materials, while only $35(15.84 \%)$ stated that their principals did not provide teaching and learning resourcesThe findings implied that the majority of principals in Meru County provide their teachers and students with the resources they required to undertake teaching and learning processes. From these findings, it was expected that good performance amongst the students should be recorded as Maicibi (2003) was of the opinion that adequate provision of teaching and learning resources should trigger good performance by the students.

Table 1: Principals' Chi-Square-Provision of Teaching Resources

\begin{tabular}{|c|c|c|c|c|c|c|}
\hline $\begin{array}{l}\text { Availability of teaching / } \\
\text { Learning resources } \\
\text { andsupervision }\end{array}$ & & $\mathrm{N}=92$ & Poor & Average & Good & - \\
\hline \multicolumn{7}{|l|}{ a) Teaching resources } \\
\hline \multirow{4}{*}{ Mathematics syllabus } & \multirow[t]{2}{*}{ unsatisfactory } & $\mathrm{F}$ & 65 & 8 & 1 & \multirow[t]{4}{*}{0.039} \\
\hline & & $\%$ & 70.6 & 8.7 & 0.01 & \\
\hline & \multirow[t]{2}{*}{ Satisfactory } & $\mathrm{F}$ & 5 & 9 & 4 & \\
\hline & & $\%$ & 5.4 & 9.8 & 4.3 & \\
\hline \multirow{4}{*}{$\begin{array}{l}\text { Adequate departmental teaching } \\
\text { and revision materials }\end{array}$} & \multirow[t]{2}{*}{ unsatisfactory } & $\mathrm{F}$ & 67 & 8 & 1 & \multirow[t]{4}{*}{0.035} \\
\hline & & $\%$ & 72.8 & 8.7 & 1.1 & \\
\hline & \multirow[t]{2}{*}{ Satisfactory } & $\mathrm{F}$ & 3 & 9 & 4 & \\
\hline & & $\%$ & 3.2 & 9.8 & 4.3 & \\
\hline \multirow{4}{*}{$\begin{array}{l}\text { Schemes of work made and } \\
\text { checked }\end{array}$} & \multirow[t]{2}{*}{ unsatisfactory } & $\mathrm{F}$ & 44 & 3 & 0 & \multirow[t]{4}{*}{0.001} \\
\hline & & $\%$ & 47.8 & 3.3 & 0 & \\
\hline & \multirow[t]{2}{*}{ Satisfactory } & $\mathrm{F}$ & 26 & 15 & 5 & \\
\hline & & $\%$ & 28.3 & 16.3 & 5.4 & \\
\hline \multirow{4}{*}{$\begin{array}{l}\text { Teaching resources adequate, } \\
\text { text books and revision } \\
\text { materials }\end{array}$} & \multirow[t]{2}{*}{ unsatisfactory } & $\mathrm{F}$ & 50 & 2 & 0 & \multirow[t]{4}{*}{0.282} \\
\hline & & $\%$ & 54.4 & 2.2 & 0 & \\
\hline & \multirow[t]{2}{*}{ Satisfactory } & $\mathrm{F}$ & 20 & 15 & 5 & \\
\hline & & $\%$ & 21.7 & 16.3 & 5.4 & \\
\hline
\end{tabular}


The findingsimplied that when principals ensure that their teachers and students had sufficient educational resources, they facilitated effective learning and teaching processes. It allows the teachers to adequately share the resources to ensure that the learning process is meaningful. According to Friend and Cook (2010) provision of adequate teaching and learning resources ensures that there is improvement in the programmed instructions.

Therefore, for teachers to adequately instruct the students, they needed to have adequate textbooks and other resources.

This is more so for the weak students whereby the adequate provision of revision textbooks and classroom arrangement where they were seated with students who performed better could help improve their performance. Therefore, for principals to feel the impact of adequate provision of resources, they should frequently monitor the resources to ensure they are adequate and work with the teachers to ensure that these resources were effectively utilized to benefit all the students.

It was seen that all the schools with good performance and the majority $15(16.3 \%)$ of those with average performance had satisfactory schemes of work while the majority of schools with poor performance $44(47.8 \%)$ had unsatisfactory schemes of work. These findings were supported by the chi-square findings where a $\mathrm{p}$ value of 0.001 implies that satisfactorily made and checked schemes of work have a significant effect on the school's performance.

Table 2: Chi-Square-Provision of Learning Resources

\begin{tabular}{|c|c|c|c|c|c|c|}
\hline Learning Resources & & $\mathrm{N}=92$ & Poor & Average & Good & P-Value \\
\hline \multirow{4}{*}{ Enough textbooks } & \multirow[t]{2}{*}{ Unsatisfactory } & $\mathrm{F}$ & 60 & 1 & 1 & \\
\hline & & $\%$ & 65.2 & 1.1 & 1.1 & \multirow{3}{*}{0.000} \\
\hline & \multirow[t]{2}{*}{ Satisfactory } & $\mathrm{F}$ & 10 & 16 & 4 & \\
\hline & & $\%$ & 10.9 & 17.4 & 4.4 & \\
\hline \multirow{4}{*}{$\begin{array}{l}\text { Teaching aids for } \\
\text { Mathematics e.g., } \\
\text { Mathematical tables, set } \\
\text { square. }\end{array}$} & \multirow[t]{2}{*}{ Unsatisfactory } & $\mathrm{F}$ & 44 & 8 & 2 & \multirow[t]{4}{*}{0.248} \\
\hline & & $\%$ & 47.8 & 8.7 & 2.2 & \\
\hline & \multirow[t]{2}{*}{ Satisfactory } & $\mathrm{F}$ & 26 & 9 & 3 & \\
\hline & & $\%$ & 28.3 & 9.8 & 3.3 & \\
\hline \multirow{4}{*}{ School financially stable } & \multirow[t]{2}{*}{ Unsatisfactory } & $\mathrm{F}$ & 65 & 8 & 1 & \multirow[t]{4}{*}{0.021} \\
\hline & & $\%$ & 70.7 & 8.7 & 1.1 & \\
\hline & \multirow[t]{2}{*}{ Satisfactory } & $\mathrm{F}$ & 5 & 9 & 4 & \\
\hline & & $\%$ & 5.4 & 9.8 & 4.3 & \\
\hline \multirow{4}{*}{$\begin{array}{l}\text { Student competitions in } \\
\text { Math's internally }\end{array}$} & \multirow[t]{2}{*}{ Unsatisfactory } & $\mathrm{F}$ & 12 & 1 & 0 & \multirow[t]{4}{*}{0.317} \\
\hline & & $\%$ & 13.0 & 1.1 & 0 & \\
\hline & \multirow[t]{2}{*}{ Satisfactory } & $\mathrm{F}$ & 58 & 16 & 5 & \\
\hline & & $\%$ & 63.0 & 17.4 & 5.4 & \\
\hline \multirow{4}{*}{$\begin{array}{l}\text { Students' competition in } \\
\text { Math's externally }\end{array}$} & \multirow[t]{2}{*}{ Unsatisfactory } & $\mathrm{F}$ & 52 & 18 & 2 & \multirow[t]{4}{*}{0.000} \\
\hline & & $\%$ & 56.5 & 19.6 & 2.2 & \\
\hline & \multirow[t]{2}{*}{ Satisfactory } & $\mathrm{F}$ & 18 & 13 & 3 & \\
\hline & & $\%$ & 19.6 & 14.1 & 3.3 & \\
\hline
\end{tabular}

In regards to learning resources, the Table 2 shows that satisfactory provision of textbooks significantly affectedschool's performance in Mathematics with a p-value of 0.000 . This was further supported by the findings showing that the majority of schools with unsatisfactory provision of textbooks $60(65.2 \%)$ were those that performed poorly. 
Financial stability was also found to have a significant effect on Mathematics performance at $p$ value 0.021 whereby the majority of poorly performing schools $65(70.7 \%)$ were not financially stable while the majority four $(4.3 \%)$ of the schools with good performance were financially stable. Fullan and Miles (1992) asserted that performance requires resources for teaching, substitution, to acquire new space and materials and most significantly for time.

Berman and McLaughlin (1976) found that a significant level of human resource support was important, and that student's performance would not have been possible without proper financial support. Materials needed for teaching and learning materials were essential for any learning programme to be implemented as meaningful learning was made possible with materials being provided.

The principals were often faced with this challenge as the funds availed to them were not sufficient for them to invest in teaching and learning resources. As such, the principals were often forced to only purchase exercise books and a few textbooks to be shared with many students.

This implies that revision materials were rarely included in the budgeting of books. Therefore, as Atieno (2018); Mugambi (2015) and Ndege (2017) argued, the most common challenge facing the principal's provision of teaching and learning resources was lack of financial ability to ensure that their teachers and students had adequate textbooks and other teaching and learning resources to ensure that meaningful learning occurs in the classroom.

These findings are in line with Bicknell, \& Riley, (2012) who claim that Mathematics competition plays a key role in motivating teaching and learning since motivation can be extrinsic. This implies that motivation can from activities and factors such as prestigious recognitions, being selected for further competitions, and being provided with awards and certificates.

Table 3: Chi-Square-Teacher Motivation

\begin{tabular}{|c|c|c|c|c|c|c|}
\hline $\begin{array}{l}\text { Teacher motivation in } \\
\text { Mathematics }\end{array}$ & & $\mathrm{N}=92$ & Poor & Average & Good & $\begin{array}{l}\text { P- } \\
\text { Value }\end{array}$ \\
\hline \multirow{4}{*}{$\begin{array}{l}\text { Teacher/school collaboration } \\
\text { between schools for } \\
\text { Mathematics }\end{array}$} & \multirow[t]{2}{*}{ Unsatisfactory } & $\mathrm{F}$ & 58 & 3 & 0 & \multirow[t]{4}{*}{0.042} \\
\hline & & $\%$ & 63.0 & 3.3 & 0 & \\
\hline & \multirow[t]{2}{*}{ Satisfactory } & $\mathrm{F}$ & 12 & 14 & 5 & \\
\hline & & $\%$ & 13.0 & 15.2 & 5.4 & \\
\hline \multirow{4}{*}{ Established office for HOD } & \multirow[t]{2}{*}{ Unsatisfactory } & $\mathrm{F}$ & 51 & 16 & 4 & \multirow[t]{4}{*}{0.171} \\
\hline & & $\%$ & 55.4 & 17.4 & 4.35 & \\
\hline & \multirow[t]{2}{*}{ Satisfactory } & $\mathrm{F}$ & 19 & 1 & 1 & \\
\hline & & $\%$ & 20.7 & 1.1 & 1.1 & \\
\hline \multirow{4}{*}{$\begin{array}{l}\text { School/principal/HOD } \\
\text { strategies for Mathematics }\end{array}$} & \multirow[t]{2}{*}{ Unsatisfactory } & $\mathrm{F}$ & 49 & 7 & 1 & \multirow[t]{4}{*}{0.021} \\
\hline & & $\%$ & 53.3 & 7.6 & 1.1 & \\
\hline & \multirow[t]{2}{*}{ Satisfactory } & $\mathrm{F}$ & 21 & 10 & 4 & \\
\hline & & $\%$ & 22.8 & 10.9 & 4.4 & \\
\hline \multirow{4}{*}{$\begin{array}{l}\text { Mathematics } \\
\text { instruments } \\
\text { protractor }\end{array}$} & \multirow[t]{2}{*}{ Unsatisfactory } & $\mathrm{F}$ & 55 & 0 & 0 & \multirow[t]{4}{*}{0.049} \\
\hline & & $\%$ & 59.8 & 0 & 0 & \\
\hline & \multirow[t]{2}{*}{ Satisfactory } & $\mathrm{F}$ & 15 & 17 & 5 & \\
\hline & & $\%$ & 16.3 & 18.5 & 5.4 & \\
\hline \multirow{4}{*}{$\begin{array}{l}\text { Special room with grid } \\
\text { board, globe, charts etc. }\end{array}$} & \multirow[t]{2}{*}{ Unsatisfactory } & $\mathrm{F}$ & 56 & 11 & 4 & \multirow[t]{4}{*}{0.398} \\
\hline & & $\%$ & 60.9 & 11.9 & 4.4 & \\
\hline & \multirow[t]{2}{*}{ Satisfactory } & $\mathrm{F}$ & 14 & 6 & 1 & \\
\hline & & $\%$ & 15.2 & 6.5 & 1.09 & \\
\hline teacher/student & Unsatisfactory & $\mathrm{F}$ & 41 & 12 & 3 & 0.660 \\
\hline
\end{tabular}


International Journal of Education (IJE) Vol.9, No.3, September 2021

\begin{tabular}{|c|c|c|c|c|c|c|}
\hline \multirow[t]{3}{*}{ relations } & & $\%$ & 44.6 & 13.0 & 3.3 & \\
\hline & \multirow{2}{*}{ Satisfactory } & $\mathrm{F}$ & 29 & 5 & 2 & \\
\hline & & $\%$ & 31.5 & 5.4 & 2.2 & \\
\hline \multirow{4}{*}{ Mathematics radio sessions } & \multirow[t]{2}{*}{ Unsatisfactory } & $\mathrm{F}$ & 66 & 0 & 0 & \multirow[t]{4}{*}{0.032} \\
\hline & & $\%$ & 71.7 & 0 & 0 & \\
\hline & \multirow[t]{2}{*}{ Satisfactory } & $\mathrm{F}$ & 4 & 17 & 5 & \\
\hline & & $\%$ & 4.4 & 18.5 & 5.4 & \\
\hline \multirow{4}{*}{ Computer laboratory } & \multirow[t]{2}{*}{ Unsatisfactory } & $\mathrm{F}$ & 60 & 15 & 4 & \multirow[t]{4}{*}{0.895} \\
\hline & & $\%$ & 65.2 & 16.3 & 4.4 & \\
\hline & \multirow[t]{2}{*}{ Satisfactory } & $\mathrm{F}$ & 10 & 2 & 1 & \\
\hline & & $\%$ & 10.9 & 2.2 & 1.1 & \\
\hline
\end{tabular}

Analysis of chi-square showed a positive correlation between teachers/school collaboration and Mathematical performance in schools. These findings were supported by the chi-square results which showed that teachers/schoolscollaboration had a significant effect on the school's performance in Mathematics. These findings were statistically significant at p-value 0.042.

From these findings, it was seen that in the majority of schools, there was insufficient teacher/school collaboration. Often, the teachers were left to their own devices. They were left to deal with challenges in the acquisition of teaching and learning resources and to address the challenges in dealing with students.

Therefore, by avoiding teachers/schools collaboration, principals fail in supporting their teachers, yet it was their duty to ensure that the teachers receive all the support they require. These findings were in line with the sentiments by Hou, Cui and Zhang (2019) who argue that collaboration is the foundation of good outcomes in any organization.

These positive outcomes were not excluded from educational outcomes. They posit that for schools to enjoy the positive outcomes of the learning process, collaboration between all the stakeholders in paramount.

These findings implied that in schools, the demand for collaboration between the school and its teachers is paramount. It provides an avenue for the teachers to discuss different issues with their principals, come up with joint goals for the students and align these goals with the student's capabilities and the school's resources.

The teachers would also feel that their input was valued and their ideas appreciated which in turn improved their productivity levels. The same sentiments were also expressed by Hallinger, and Heck, (2010) who claimed that collaborative leadership approaches in schools promoted the performance of students. It ensures that every approach developed by the school administration is acceptable and enforceable by the Mathematics teachers. Mathematics teachers could work closely with the principals to acquire the necessary resources to allow for the adoption of the strategies in the classroom.

The school/principal/HOD strategies for Mathematics were found to have a significant association with the school's performance at $\mathrm{p}$ - value 0.021 .

The findings showed that the majority of the schools, had a well-established HOD department, but were found to bear no statistically significant effect on the performance of Mathematics. However, the findings further shows that the principal/school/HOD strategies had a statistically significant effect on the student's performance in Mathematics. 
The chi-square significant $\mathrm{p}$ value $(\mathrm{p}=0.049)$ which was found supported these results, showing that schools with satisfactory provision of Mathematics instruments had an increased probability of performing well in Mathematics. Contrary, there was no significant association between special rooms and Mathematics performance at $\mathrm{p}$ value 0.398. According to Sammons, Gu, Day, and Ko (2011) provision of instruments in schools was critical for the performance of students.It enables the teachers to demonstrate and have the students practically perform the different aspects of the lessons. This was a more effective means of instructing the students. They got to transfer the abstract concepts of the subject into a meaningful and understandable way of learning

A significant association was found between Mathematics performance and Mathematics radio sessions $(\mathrm{p}=0.032<0.05)$ where the majority of the schools with poor performance in Mathematics had unsatisfactory radio sessions 66 (71.7\%) and all the schools with good and average performance had satisfactory radio sessions. Contrary, there was no association between Mathematics performance in KCSE and availability of computer rooms. Radio sessions were important in exposing students to a new mode of learning aside from the normal lecture sessions adopted by the teachers.

\section{Conclusions}

In conclusion, many schools failed to invite Mathematics specialists despite the evidence that it can positively impact performance in Mathematics among secondary school learners.

The researcher also concluded that attendance of seminars were minimal and non-existent in majority of the schools and considering that there is a significant association between teacher's attendance of seminars and student performance in Mathematics

Regarding the principals' organization of Mathematics contests, it was concluded that schools in Meru County did not generally organize external Mathematics contests. There was also a significant association between organization of Mathematics contests and poor performance.

Lastly, the study concluded that the provision of teaching and learning resources are generally unsatisfactory which had a negative impact of the performance of schools. Therefore, the study concluded that the provision of teaching and learning resources affected school performance in Mathematics.

\section{RECOMMENDATIONS}

The study recommends these strategies to lead to improved performance in Mathematics KCSE in Meru County, in particular, and in Kenya:

Principals should ensure teachers' and students' exposure to various skills and strategies for approaching Mathematical problems by inviting Mathematics specialiststo give motivation to learners and teachers.

Principals should frequently invite the external resource persons every term to reinforce skills and concepts that are already imparted to learners.

Principals should use more than one strategy in teaching their learners.

The provision of teaching and learning resources should be enhanced to support the teaching and learning of Mathematics across secondary schools. 


\section{REFERENCES}

[1] Atieno, A. J. (2014). Influence of Teaching and Learning Resources on Students' Performance in Kenya Certificate of Secondary Education in Free Day Secondary Education in Embakasi District, Kenya.

[2] Berman and McLaughlin, (1976) Play and divergent problem solving: Evidence supporting a reciprocal relationship. Early Education and Development, 10(4): 419 - 44.

[3] Bicknell, B., \& Riley, T. (2012). The role of competitions in a mathematics programme. APEX: The New Zealand Journal of Gifted Education, 17(1), 25-34.

[4] Bryman (2012) Relationships between symbolic play, functional play, verbal and non-verbal ability in young children. Int J Lang CommunDisord. 35(1):117-27.

[5] Friend, M. \& Cook, L. (2010). Interactions: Collaboration skills for school professionals (6thed.). Columbus, $\mathrm{OH}$ : Merrill. Pretoria.

[6] Fullan and Miles, (1992) Pretense and possibility--a theoretical proposal about the effects of pretend play on development: comment on Lillard et al. (2013). Psychol Bull. 139(1):40-4.

[7] Hallinger, P., \& Heck, R. H. (2010). Collaborative leadership and school improvement: Understanding the impact on school capacity and student learning. School Leadership and Management, 30(2), 95-110.

[8] Hou, Y., Cui, Y. \& Zhang, D. Impact of instructional leadership on high school student academic achievement in China. Asia Pacific Educ. Rev. 20, 543-558 (2019). https://doi.org/10.1007/s12564019-09574-4

[9] Maicibi, A. N. (2003). THE APPLICABILITY () F HIRIRZIER (," S TVVO) FACT () IR TIJ IEORY () N THIE JUNIOR NON. ACADEMIC STAFF OF MIA KEIRERE UNIVERSITY.

[10] Mugambi, M. D. (2015). The Role of Principals in Promoting Students Academic Performance in Secondary Schools in Tigania West Sub-County, Meru County, Kenya. A Research Project Report Submitted in Partial Fulfillment of the Requirement for the Award of Master of Education Degree of Kenyatta University.

[11] Ndege, R. W. (2017). Influence of principals' administrative practices on student's performance at KCSE in Buteere Sub-County, Kenya. A Research Project Report Submitted in Partial Fulfillment of the Requirement for the Award of Master of Education Degree of Kenyatta University.

[12] Sammons, P., Gu, Q., Day, C., \& Ko, J. (2011). Exploring the impact of school leadership on pupil outcomes: Results from a study of academically improved and effective schools in England. International Journal of Educational Management, 25(1), 83-101.

[13] Verma, S. K., \& Thakur, R. S. (2017). Fuzzy Association Rule Mining based Model to Predict Students' Performance. International Journal of Electrical \& Computer Engineering (2088-8708), 7(4).

\section{AUTHOR}

MaingiKirikua is currently a $\mathrm{PhD}$ candidate pursing a doctorate degree in educational administration at Maasai Mara university. His research interests are educational administration, curriculum development and public policy development.

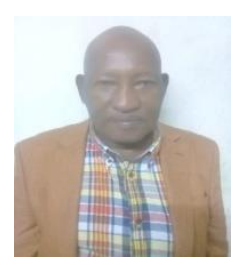

